ROCZNIKI TEOLOGICZNE

Tom LXVII, zeszyt 7 - 2020

DOI: https://dx.doi.org/10.18290/rt20677-3

GEERT FRANZENBURG

\title{
RECONCILIATION NEEDS REMEMBRANCE: THE GERMAN-POLISH CASE
}

\begin{abstract}
A b stract. The paper emphasizes the relationship between reconciliation and remembrance by evaluating examples of German - Polish discourses during the 20th century concerning the intrapersonal, interpersonal, intracultural, intercultural, and transcultural aspects from an ecumenical oriented Lutheran point of view. Based on research about remembrance, reconciliation (and resilience), and on the partnership between Münster and Lublin, it suggests a curriculum of reconciliation oriented remembrance for common projects of ecumenical and transcultural dialogue by sharing experiences and by facilitating rituals, which make them sustainable.
\end{abstract}

Key words: remembrance; reconciliation; dialogue; ecumenical.

\section{INTRODUCTION}

In a resolution adopted by the General Assembly of the UN on the sixtieth anniversary of the end of the Second World War 2004, was characterized as an "inspiration" for all UN-members to "unite their efforts in dealing with new challenges and threats." They should make "every effort to settle all disputes by peaceful means" conform with the UN-Charter and "in such a manner that international peace and security are not endangered" (Jewish Virtual Library, n.d.). These words underline the global character of peace and reconciliation by international cooperation, as the charta emphasizes: Underlining the progress made since the end of the Second World War in overcoming its legacy and towards establishing reconciliation, international and regional cooperation and the promotion of democratic values, human rights and fundamental freedoms, in particular through the United Nations,

Dr. Geert Franzenburg - WWU Münster, Evangelisch-Theologische Fakultät, Seminar für Praktische Theologie und Religionspädagogik; address for correspondence: Universitätsstraße 13-17, 48143 Münster; address for correspondence — e-mail: franz_00@uni-muenster.de. 
and the establishment of regional organizations and other appropriate frameworks. Therefore, the UN declared 8-9 May as a time of remembrance and reconciliation besides the individual days of victory, liberation and commemoration in the member stats, and invites also non-governmental organizations and individuals to observe annually either one or both of these days in an appropriate manner to pay tribute to all victims of the Second World War. Based on this official declaration as a framework, the research evaluates, how remembrance could facilitate reconciliation in intercultural contexts according to the Word War II memories; therefore, it intends to develop a curriculum of reconciliation oriented remembrance, which assists young learners from different countries sharing their family and national remembrance cultures, but also their stereotypes, belief systems and models of interpretation. Thus, their own memory culture can be compared with the official ones, in order to detect manipulations by memory politics (A. Assmann 2011; J. Assmann 2006; Assmann and Czaplicka 1995; Erll 2011; Troebst 2005; Welzer 2008). Particularly the common complex history of Polish and German people facilitates such real or virtual research encounters.

\section{RESEARCH}

In order to develop a curriculum of reconciliation oriented remembrance in a contextual way, about 500 students from Germany, Latvia, and Poland were asked to answer questions about their coping strategies with individual and collective remembrance cultures (Franzenburg 2015). Their answers were evaluated following the concept of Grounded Theory. In a further step, important (Glaser and Strauss 1967) historical events and aspects of the German-Polish relationship (age of knights, 1918, World War II) were evaluated concerning stereotypes, discourse, interculturalism and similar topics, in order to find elements of a grammar of remembrance which facilitates a curriculum of reconciliation (and resilience) oriented remembrance (Franzenburg 2012/2013/2016c). A main focus of the current research is the category of values and religion by evaluating narratives, rituals, belief systems, and attitudes, which demonstrate and explain, how individuals and groups are coping with biographical challenges of any kind. As a contextual approach, the research evaluates, how memory, rituals and rules work together in particular situations and contexts: 
- The first context is the family, where children learn the first elements of memory-culture (FIVUSH 2007).

- The second context consists of peer-groups, which are connected by common elements of cultural identity, and which are connected by a common sense of belonging.

- The third context is built by nation, state, community, which is characterized by common heritage, which often is complex and inhomogeneous.

\section{The RATiOnALE}

The intended curriculum consists of the following stages:

Intrapersonal stage - personal competence

The first step of the intended curriculum emphasizes the memory-aspect of religious and cultural identity within a singular historical person, who has to cope with other cultural identities, and has to learn his or her own identity from the past for the future by coping with stereotypes and belief systems.

Interpersonal stage - dialogical competence

In a second step, communication styles and strategies are evaluated in order to develop non-violent communication competencies, particularly in intercultural contexts and encounters.

Intra-cultural stage - common remembrance competence

The third step concerns the belief systems, attitudes, and rituals of a group, which is confronted with alternative models; thus, people have to become aware of their traditions and narratives, and have to distinguish between patriotism and nationalism, in order to avoid discrimination and conflicts.

Intercultural stage - intercultural competence

As fourth step during the curriculum, individuals and groups will interpret strangers and strange attitudes, rituals, and belief systems as enrichment instead of dangerous by experiencing encounters and model learning.

Transcultural stage - universal competence

The final step actualizes the learning results of the former steps by common projects, which combine individual and collective memory, experiences, attitudes and rituals into a mosaic of different parts built on a common basement. All these steps of the curriculum are exercised by evaluating docu- 
ments in a creative way (official documents, Ego-documents, discoursedocuments: texts, pictures, monuments).

\section{RESULTS}

Evaluating the answers of the pupils, the following observations are remarkable:

\section{Intrapersonal}

Concerning the individual person with his/her own socialization, personality, memories, emotions, expectations, the evaluation of the answers shows following results:

According to the family socialization of the learners, the stereotypes, belief systems, rituals and narratives of the family influence how children cope with crisis, with foreign cultures and with conflicts. Polish pupils emphasize - similar to Germans (and Latvian) - family as a core-aspect of cultural identity School education and peer influence in a similar way by sharing pictures, films, narrations, symbols, rituals. Pupils learn basic information about their family and about themselves, Home and immediate surroundings, everyday life (times, activities), health and sports, travelling and tourism, natural environment, technology, media, Polish social studies: (symbols, heroes, celebrations, customs, places). Therefore, the answers emphasize patriotic issues and national identity (Warsaw Ghetto-war, Polish independence day, Mission in Poland, Constitution of May 1791, struggle of Tannenberg, revolt in Silesia, end of communism in 1989, Polish divisions) with a focus on church and religion, exemplified by the Polish Child's Catechism of Władysław Bełza and other writings including poems for children (Jan Brzechwa, Julian Tuwim and others). This tradition also means knowing Polish poems, songs, proverbs, and sayings and to describe Polish landscape with regard to particular seasons and corresponding traditions; although these are not mentioned, the answers nevertheless allow the conclusion that the pupils are familiar with these elements of family tradition and cultural identity. The answers further show that the pupils are aware of the history of Poland from the times of Poland's baptism to solidarity times and regaining independence in 1989, and identify with Polish culture and tradition, they also proof knowledge about Polish kings and presidents according to the curriculum and also about the Polish-Lithuanian Commonwealth, and are also interested in the modern history of Poland. Thus, they mention different kings of Poland (Władysław Jagiełło, Mieszko I Kazimierz Wielki, Jan III Sobieski) 
the national poet Adam Mickiewicz, the national hero Tadeusz Kościuszko (upspring 1794), partisans of World War II, and the former president Lech Wałęsa. German students argue more individualistic and anti-ideologically than Polish, who more emphasize on the common traditions and collective memories. Background for such attitude is German history teaching, where pupils should develop a reflexive historical awareness/consciousness (Franzenburg 2015).

Exemplified by the situation after 1918, the Polish answers show interest in the Polish history since 1918. Their knowledge is not only based on cultural memory, but on communicative memory by family narrations, particular the different uprisings since 1918 and the political systems in Poland, particularly of the Second Republic. Perhaps - by family narrations or school books - they became aware of stereotypes, which were illustrated during World War I by cartoons, which compared the Polish attitude towards Germany with a (German) wolf within a group of (Polish) rabbits (MuCHA 1914, 7), like in Germany 1918 German and Polish house-keeping was compared as between a systematic (German) and a chaotic (Polish) model (Kladderadatsch 1919).

Considering such and similar cartoons and other examples of illustrated stereotypes by contextualizing them facilitates - as the first step during the curriculum of resilience oriented remembrance new open minded attitudes towards the other nation, particularly during intercultural encounters.

\section{Interpersonal}

Concerning the aspect of dialogue between two persons with different backgrounds, experiences, impressions, expressions and expectations, the evaluation of the answers demonstrate that remembering can facilitate and support fruitful encounters, but also avoid and prevent them. Concerning the German-Polish relationship, the model of knights and heroes exemplifies such chances and challenges: The Polish students underline in their answers that in remembrance-days the most important facts and heroes were remembered. Emphasizing on heroes, they illustrate the educational model to learn, particularly the Polish kings and nobles and the different upbringings during Polish history. They also emphasize on the conviction that only an event should be remembered, which is grounded in experiences. They see memoryculture as characterized by important jubilees, where the care for traditions is in the focus. They underline the need for young people to get to know, where they come from. Others emphasize on the method and interpret memory-culture as the way, people are used to remember. These answers un- 
derline that the students follow the educational rules from their schools. While in Poland books about Egypt and World Wars are very popular, German pupils prefer narrations. Whether the particular interest of Polish (and Latvian) students for knights is influenced by the common tradition of German Knights in these regions since Middle ages, is open for research, as well as the particular interest for Romans (not for the Germans). It might also depend on the school-books, which emphasize on the tradition of knights in Poland. That Polish (and Latvian) pupils show such significant interest in wars (more than German). The results suggest using peer-groups and encounters as a didactic approach (group-work), and to be aware of the value of collective experiences. That polish pupils are more interested in Knights than German, might be influenced by books of Artur Oppman ("Sleeping Knights"), Zbigniew Nienacki ("Pan Samochodzik and the Templar Knights"), Ewa Nowacka ("Legends of the Knights"), Henryk Sienkiewicz, Nobelprice-winner for literature 1905 ("With Fire and Sword", "The Knights of the Cross"), and others. Although Germany is the land of castles and knights, and many towns with origins in the Middle ages celebrate this tradition, the German pupils prefer more 'exotic alternatives,' such as adventures in Egypt or America (Franzenburg 2015).

Following the curriculum of reconciliation oriented remembrance in a contextual way, the way from conflicts towards non-violent communication leads through models of violent communication, illustrated and exemplified by a knight-fight; Fighting with the lance or with a sword illustrates the change of distance and contact, the helmet symbolized the partial view towards the partner in communication. Both partners can use their shields to avoid contact, but also to serve or transport each other.

\section{Intracultural}

Concerning the identities within a common culture (nation, society, group, milieu), the evaluation of the answers explains and presents the crucial distinction between patriotism and nationalism, exemplified by ambivalent heroes, rituals, and narrations, and depending from different historical experiences. Thus, Polish answers emphasize on the aspect of patriotism, while German students emphasize on the prevention-aspect of remembrance: The answer "Who does not remember, will be forgotten some day" (male 17) is like a symbol for this attitude and point of view, which is based on individuality, intercultural encounter and tolerance, which they experience since childhood in family-socialization and education. Polish (and Latvian) students are also emphasizing the heroism of the ancestors, while the Ger- 
mans acknowledge this issue as a taboo because of their Nazi-past. All students in the three countries agree that memories belong to human existence, but Polish students emphasize on the national value (love of the homeland as part of cultural identity), while Germans put the stress on the individual benefits (prevent making faults), but all agree the need to understand foreign history and experiences by authentic narrations. German pupils should evaluate past events and integrate them into a historical framework, and thus participate in the current memory-culture by analyzing historical narrations concerning particular models of interpretation (re- and deconstruction) (FrAnzenburg 2015). These purposes can be evaluated from the answers, which show a critical approach towards traditions. Therefore, the German emphasizing individual responsibility for tolerance and understanding might be a key for collective responsibility and a sense of belonging and community; on the other hand, Germans could learn to distinguish between patriotism and nationalism and to cope with their own attitude towards their homeland and to prevent aggressive ones. For Polish people, there is a particular interest to interpret Auschwitz from a victim-perspective, while young Germans often blame their ancestors, and simultaneously pretend that they are born too late to be responsible for such crime. While the German students also in this context underline the individual responsibility and the value of democratic tolerance (preventing conflicts by learning from each other), and put the stress on the variety of cultures with common roots and values, Polish (and Latvian) students suggest to transfer national values and cultural identity from one generation to the other (patriotism, glorious actions, important persons, times, places). For them remembrance is useful because historical knowledge prevents false information. All participants agreed in their answers that people have to learn from the past to the future in order to avoid and to prevent stereotypes and stigmatisation, and to combine own experiences, interpretations and attitudes with collective ones. Therefore, a curriculum for such learning should recognize intrapersonal, interpersonal, intracultural, intercultural, and transcultural aspects of memory learning following a kind of grammar of remembrance, which integrates these stages and aspects within a theory of hermeneutical remembrance. All participants share the opinion that memory-learning is an interdisciplinary issue, because it combines different approaches and experiences helps to draw benefit from foreign and former experiences and mistakes; as a part of global history and part of everyday life of any person memories help to understand one's own (national) roots and attitudes and foster moral attitudes. Other than Polish (and Latvian) students Germans also in this context focus on the individual 
responsibility according to the intercultural and inter religious challenges and according to the German (Nazi) past. Polish (and Latvian) students interpret past experiences and their remembrance as part of their own cultural identity and see, therefore, memory as an enrichment of their cultural life, especially when remembering the rich culture of their national past: similar to Germans and Polish students they focus not only on school, but on the family and society for a better historical understanding by narrations from older people, not only data and facts. Polish students agree with the suggestion to learn more about the past, not only in lessons, but in life. Similar observations can be made according to the responsibility towards following generations: Germans focus on the responsibility of parents for the education of future leaders. Coping with one's own challenging history and tradition facilitates a more complex structure (FRANZENBURG 2015).

Concerning the curriculum of reconciliation oriented remembrance historical examples can contextualize such considerations by examples of reconciliation, such as Wilm Hosenfeld, who rescued as a member of German Wehrmacht many Polish Jews in Warsaw, Willy Brandt, who took over responsibility of Germans in the Warsaw Ghetto 1943; also the members of the community of the nail-cross of Coventry symbolize with their common prayer such attitude.

\section{Intercultural}

Concerning encounters of different groups, communities or nations with different cultural traditions, the evaluation of the answers emphasize the particular role of models. While in the former soviet republics the German genocide is compared with Stalinism, there is another conflict of memorycultures between Germany and Poland, which, however, has no direct echo in the answers of the pupils. For their parents and grandparents, the expelled Germans were the last victims of Hitler's war, subjected to ethnic cleansing as a by-product of the brutality of the German army and National Socialism. For others, the diasporic Germans were victims of Red Army atrocities. In both interpretations, the expelled German civilians are, in general, depicted as innocent victims of a brutal ethnic cleansing. In the contrary, Poles see the war as a catastrophic era of German malevolence against the Polish people and the extinction of their long-awaited sovereignty. Poles emphasize the fact that Poland suffered more than almost any other nation during the war, primarily the fault of the Germans, having lost about $1 / 5$ of their total population. Like the Russians and Soviets, the Germans as the ethnic identity altogether were seen as the mortal enemies of Polish nationality and statehood. 
To be German was to be a Nazi regardless of one's personal ideology or nationality, although the German minority that had settled in Poland, often for as many as seven centuries since the rule of the German Teutonic Order. By reminding of the traumata of War they make aware of the dangerous roots of conflicts and avoid repetitions of faults and facilitate a tolerant attitude by explaining the backgrounds of imperialism and nationalism in a narrative way and by facilitating empathy for suffering and for other cultures. First of all parents and grandparents should motivate to search for traces of roots and to appreciate one's one life, attitude, national roots and convictions as a contribution to intercultural dialogue and global peace. Polish students also recognize national history as a part of human history, especially concerning the aspect of war and national independence; they agree that this is a task and a challenge for intergenerational learning. Therefore, they share the suggestion that this is the best way to prevent future wars and to facilitate a patriotic attitude within the young generation. While all students in the three countries underline that remembrance is useful for human morality, they use different approaches: from critical individualism (Germany), from culture (Latvia) or religious oriented patriotism (Poland). All together focus on the democratic right and task to remember from the beginning, before the remembrance died with the narrator, and have 1990 as a symbol, they underline the liberating power of remembrance and historical knowledge:

Concerning the curriculum of reconciliation oriented remembrance this particular stage can be exemplified and contextualized by Edith Stein and Otto Zaenker, who symbolize a virtual partnership between Münster (both worked there) and Breslau (Edith Stein was born there, Otto Zaenker was Bishop there); both emphasize immanence and transcendence in their writings, but from very different points of view (Edith Stein - Jewish born catholic nun, Otto Zaenker - Lutheran pastor and bishop follower of Hitler, but following the Anti-Nazi confessional church in Germany); therefore, they motivate considering models of intercultural relationships (FRANZENBURG 2016a).

Transcultural

That the pupils should research their own and the foreign history and culture by heart, develop awareness of "real" and "fictive", and integrate events chronologically is illustrated by the answers, which underline the challenge of such task: They mostly are still mixing present and past, but show an evolutionary scheme (learning facilitates better life) and suggest holistic learning: not only facts, but attitudes, emotions, and beliefs. When they emphasize on the value of memories and remembrance for present and future, 
they follow the educational concept to understand that historical research depends on requests from the presence into the past, and consists of the knowledge and interpretation of sources concerning questions and interests. Therefore, they should evaluate memory-cultures concerning their historical facts and orientations; they should follow the contextual approach and appreciate the value of a particular historical situation. The German students also emphasize on the responsibility for their children and further generations, which will one day take responsibility as leaders in society in the future; therefore, they needed the best education for their future tasks and challenges in order to avoid further wars and traumata. They agree that remembering the experiences of parent-generation and their traumata would prevent from making their mistakes again. Therefore, education as clearing up and as the opportunity to come in contact with such experiences should teach right decisions and learning-strategies, how to avoid traumata. The students also consider the challenges of such task, because nobody would know when such cruel things will happen again. Therefore, children should become aware that war is not only an thrilling adventure, but a horror for all participants, and should be informed about all aspects of life; because such things could happen at any time, they should be remembered between the generations; thus children could understand that the reasons for war and similar events can be found in human attitudes and in the exploiting of other countries; furthermore, they could develop empathy by becoming aware of traumatic experiences of their ancestors; and could develop strategies to foster a peaceful situation in their own life-world. Similarly, also Polish students characterize remembering as an important issue of cultural identity. They, too emphasize on how the ancestors (fathers) have fought for Polish freedom. Only by learning from the grandfathers' experiences one could avoid further wars, because children should learn the reasons, backgrounds and experiences connected with wars, in order to avoid further conflicts. Remembering could facilitate patriotism and thus, open the future. Therefore, teaching history and memory-culture by combining past, presence and future, and by emphasizing on important historical facts, positive and negative by the narration, are crucial, particular honouring the dead heroes and telling the truth about national history. Polish students emphasize on remembering the heroes of the past, on cultural events and traditions, which helps to understand one's cultural roots and to avoid and prevent neglecting or loosing important events. Such remembering reminds people of the value of history and of the respect towards the martyrs of the past. Although all partici- 
pants agree that there are other religious keys towards deliverance, they confirm the value of remembrance for human ethics and for coping with future challenges. While Polish (and Latvian) students put the stress on cultural aspects, Germans focus on one's own responsibility for decisions, on experiences and actions by awareness and learning and remind of negative or traumatic or aggressive memories as a challenge. Since memories are constitutive parts of human life, they should be appreciated as enrichment of the person, as an opportunity to understand history better, and to become educated and value-oriented (FranZENBURG 2015).

Following the curriculum of reconciliation oriented remembrance, this final stage can be exemplified and contextualized by the partnership between Münster and Lublin, where common intercultural projects are organized, which facilitate considering one's own socialisation, context, stereotypes, and also the chances and challenges of reconciliation and partnership.

\section{DISCUSSION}

These results underline the importance of a curriculum, which combines individual and collective aspects, different kinds of contents (documents, discourses, rituals, narrations), actors (family, school, educational, political, and religious institutions), contexts and perspectives (micro-, meso-, macro-) All these aspects together can be compared with parts of a grammar of remembrance (reminiscent morphemes, syntax, semantics, phonology, rhetoric) as an analysis instrument, as a way to get onto own and foreign experiences, and as a mediation instrument (FrANZENBURG 2016c).

Concerning such a curriculum of reconciliation oriented remembrance, the results of the evaluation of answers and documents underline that sharing models of interpretation, rituals and experiences is a key to understand how to facilitate reconciliation (and resilience) by remembrance. These considerations concern the different stages of the intended curriculum:

\section{RECONCILIATION WITH ONESELF}

Polish people, who were taught in family and school a victim stereotype concerning the Holocaust in their country, share the same challenge of reduced awareness as the Germans, who followed the myth that the Holocaust had been a hidden cruelty of some German Nazis. In both cases, a grammar 
of remembrance can facilitate a wider horizon and an open minded attitude towards other contexts. Concerning the vocabulary of remembrance, coping with stereotypes means learning more synonyms in order to decide, which one fits the particular situation (types of victims, responsibility vs. guilt etc.). Concerning the syntax of remembrance, coping with stereotypes means exploring the internal logic and coherence of messages by evaluating structures, interdependencies, hierarchies etc. (organization of Holocaust concerning the different levels, different types of statistics, role of media etc. Concerning the morphology of remembrance, coping with stereotypes means exploring the etymology of particular terms, their contextual meanings and origins (nation, autonomy, race, legal war etc.). Concerning the style and rhetoric of remembrance, coping with stereotypes means exploring the message behind particular terms and narratives, and distinguishing between fact, information, and message by asking for intentions, experiences, needs, and stereotypes behind (mother tongue, fatherland, homeland-soil, brotherhood etc.) (FranZENBURg 2016b).

\section{RECONCILIATION WITH ANOTHER PERSON}

In order to change from violent fight to non-violent dialogue, a grammar of remembrance can facilitate an appropriate atmosphere for such encounters: Concerning the vocabulary of remembrance, coping with encounters means working with synonyms in order to translate from one life-world into another ("friend(ship)", solidarity, stranger etc.). Concerning the syntax of remembrance, coping with encounters means exploring the internal logic and coherence of what the other did really say instead of constructing own messages (context, framework) Concerning the morphology of remembrance, coping with encounters means evaluating, whether both partners mutually understand, what they really said (in which sense do you mean xy?). Concerning the style and rhetoric of remembrance, coping with encounters means evaluating, why the partner exploring the different aspects of a message (information, relationship, appeal, self-expression) (FrANZENBURG 2016b).

\section{RECONCILIATION WITH ONE'S OWN COLLECTIVE MEMORY}

In order to become aware of the contexts, reasons, and backgrounds of family and social traditions, rituals and narratives, a grammar of remembrance assists people decoding and exploring them. Concerning the vocabu- 
lary of remembrance, coping with a memory culture means learning more synonyms in order to decide, which one fits the particular situation (homeland for whom? Where?) Concerning the syntax of remembrance, coping with a memory culture means exploring the internal logic and coherence of messages regarding one's memory culture, such as narrations, rituals, symbols (remembrance day, victory day, "Volkstrauertag"; flags, hymns etc.) Concerning the morphology of remembrance, coping with a memory culture means exploring the background, origin and context of such memory-culture messages (context of a hymn/monument/document/flag/symbol). Concerning the style and rhetoric of remembrance, coping with a memory culture means exploring the message behind particular terms and narratives, and distinguishing between fact, information, and message by asking for intentions, experiences, needs, and stereotypes behind (cartoons, posters, pamphlets, articles etc.) (Franzenburg 2016b).

\section{RECONCILIATION WITH OTHER GROUPS}

In order to cope with intercultural conflicts between different groups (nations, communities), a grammar of remembrance facilitates reconciliation by explaining and evaluating the context and aspects of the conflict. Concerning the vocabulary of remembrance, coping with intercultural conflicts means translating cultural patterns and terms (ruling, fighting, leader, stranger etc.). Concerning the syntax of remembrance, coping with intercultural conflicts means exploring the internal logic and coherence of cultural attitudes, belief and value systems. Concerning the morphology of remembrance, coping with intercultural conflicts means exploring the context, origin, and message of particular narratives, rituals, and values (socialism, liberalism, kingdom, genocide, Christian, Islamic etc.). Concerning the style and rhetoric of remembrance, coping with intercultural conflicts means exploring the impressions behind expressions, experiences behind expectations, stereotypes behind interpretations (rhetorical questions, hidden attacks, stereotyping, stigmatisation etc.) (Franzenburg 2016b).

\section{RECONCILIATION WITH LIFE}

When people have peace with themselves, with other individuals and groups, and with their own socialization and history, they become open for common experiences, and for a global reconciliation, which include all as- 
pects of life (individual and collective, past, present and future times, ambivalences and ambiguities etc.). A grammar of remembrance can facilitate such attitude towards life by evaluating the appropriate preconditions and frameworks Concerning the vocabulary of remembrance, coping with life means being able to communicate beyond borders of languages and cultures by developing a universal code (Esperanto, signs and symbols etc.). Concerning the syntax of remembrance, coping with life means to become aware of a message behind a particular information or argumentation (manipulation of opinions by fake news etc.). Concerning the morphology of remembrance, coping with life means transparency concerning the original and current or individual use of particular cultural elements (words, signs, symbols). Concerning the style and rhetoric of remembrance, coping with life means expressing one's impressions, feelings, expectations, and experiences in a way adequate to the current situation (awareness of analogue experiences of refuge/expellation/displacement, analogies and differences in totalitarian regimes (Hitler-Stalin) etc.) (FrANZENBURG 2016b).

\section{CONCLUSION}

The results of research and the considerations concerning a grammar of remembrance underline that reconciliation needs remembrance, because considering, evaluating and sharing experiences — individually, during dialogues, in intercultural settings or common projects - facilitates learning from the past for the future with different (interculutral) approaches: While Polish students put the stress on cultural aspects, Germans focus on one's own responsibility for decisions, on experiences and actions by awareness and learning and remind of negative or traumatic or aggressive memories as a challenge.

Because memories are constitutive parts of human life, they should be appreciated as enrichment of the person, as an opportunity to understand history better, and to become educated and value-oriented. Therefore, preventing by remembering from childhood on is their common suggestion. Different media, such as cartoons, knight play figures, names of places and monuments (Willy Brand in Warsaw), models of resistance (Wilm Hosenfeld) and religious reconciliation (Zaenker, Stein, nail cross community), or partnership, such as between Münster and Lublin, facilitate such opportunities following a kind of grammar of remembrance. Thus, not only the Ger- 
man and Polish students consider particularly the past prepares for the future, and underline the importance of cultural and historical identity in developing one's cultural identity and a view of one's identity as a part of bigger European identity.

\section{REFERENCES}

Assmann, Aleida. 2011. Cultural memory and Western civilization. Cambridge: Cambridge University Press.

Assmann, Jan, and John Czaplicka. 1995. "Collective memory and cultural identity." New German Critique, No. 65: Cultural History/Cultural Studies, 125-133.

Assmann, Jan. 2006. Religion and Cultural Memory. Stanford: Stanford University Press.

ErLl, Astrid. 2011. Memory in culture. Basingstoke: Palgrave Macmillan

FIVUSH, Robyn. 2007. "Maternal Reminiscing Style and Children's Developing Understanding of Self and Emotion." Clinical Social Work 35: 37-46.

Franzenburg, Geert. 2012. "Distance, Remembrance, Tolerance: European Remarks.” Problems of Education in the XXI Century 47: 40-49.

Franzenburg, Geert. 2013. "Displaced Values: From Remembrance To Resilience.” Problems of Education in the XXI Century 56: 59-65

Franzenburg, Geert. 2015. "Remembering rituals and rules.” Trimda Forum 4 (self-publishing).

FranzenburG, Geert. 2016a. "Der Bischof und die Nonne [The bishop and the nun]. Roczniki Teologiczne 43, z. 7: 195-206.

Franzenburg, Geert. 2016b. "Erinnertes äußern (expressing memories).” Europa-Forum Philosophie 65: $85-100$

FranzenburG, Geert. 2016c. "How to draw benefit from remembrance." Trimda Forum 5 (selfpublishing)

Glaser, Barney G., and Anselm L. Strauss. 1967. The discovery of grounded theory. Chicago: Aldine Transaction.

Troebst, Stefan. 2005. "Jalta versus Stalingrad, Gulag versus Holocaust.” In Stefan Troebst. Postkommunistische Erinnerungskulturen im östlichen Europa (post-communistic memories in Eastern Europe). Wroclaw: Wroclaw University Press.

Welzer, Harald. 2008. "Communicative Memory.” In Cultural Memory Studies, edited by Astrid Erll and Ansgar Nünning, 285-98. Berlin: De Gruyter. 


\section{POJEDNANIE WYMAGA PAMIĘCI: PRZYPADEK NIEMIECKO-POLSKI}

\section{Streszczenie}

Artykuł podkreśla zależności między pojednaniem i pamięcią poprzez ocenę, z ekumenicznie zorientowanej perspektywy luterańskiej, przykładów dyskursów niemiecko-polskich w XX wieku, dotyczących aspektów wewnątrzosobowych, międzyosobowych, wewnątrzkulturowych, międzykulturowych i transkulturowych. Opierając się na badaniach nad pamięcią, pojednaniem oraz na parnerstwie między Münster i Lublinem, formułuje pewien program jednającej pamięci jako narzędzia dla wspólnych projektów dialogu ekumenicznego i transkulturowego poprzez dzielenie doświadczeń oraz umożliwianie rytuałów, które czynią te projekty zrównoważonymi.

Słowa kluczowe: pamięć; pojednanie; dialog; ekumeniczny. 